This item was submitted to Loughborough's Research Repository by the author.

Items in Figshare are protected by copyright, with all rights reserved, unless otherwise indicated.

\title{
Re-examining the deployment of market orientation in the public leisure
} sector

PLEASE CITE THE PUBLISHED VERSION

http://dx.doi.org/10.1080/0267257X.2011.645857

PUBLISHER

Taylor and Francis / @ Westburn Publishers Ltd.

VERSION

AM (Accepted Manuscript)

LICENCE

CC BY-NC-ND 4.0

\section{REPOSITORY RECORD}

Hodgkinson, lan R., Paul Hughes, and Mathew Hughes. 2019. "Re-examining the Deployment of Market Orientation in the Public Leisure Sector". figshare. https://hdl.handle.net/2134/14764. 
This item was submitted to Loughborough's Institutional Repository (https://dspace.lboro.ac.uk/) by the author and is made available under the following Creative Commons Licence conditions.

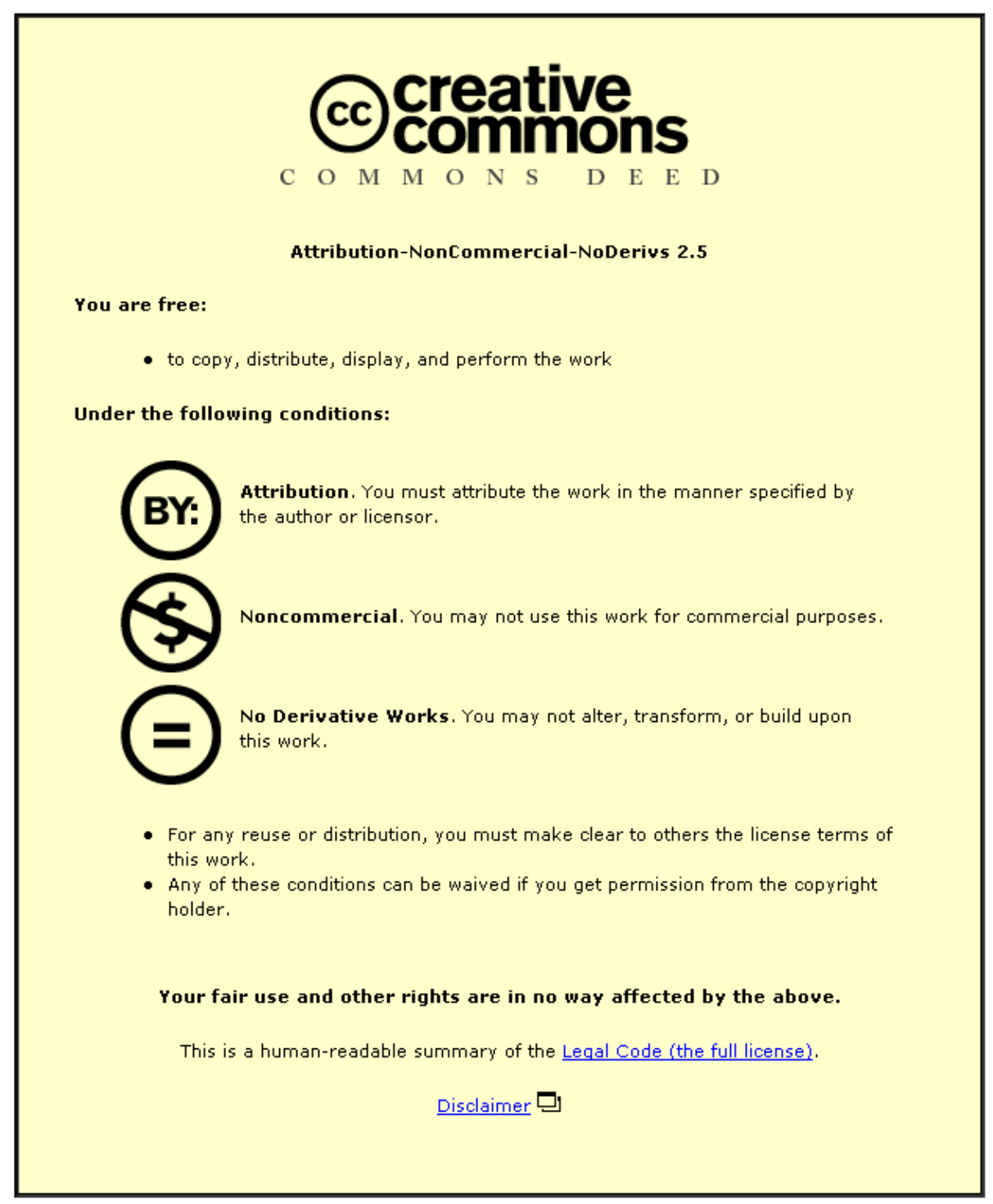

For the full text of this licence, please go to: http://creativecommons.org/licenses/by-nc-nd/2.5/ 


\title{
Re-examining the Deployment of Market Orientation in the Public
}

\section{Leisure Sector}

\author{
Ian R. Hodgkinson \\ School of Business and Economics, Loughborough University, Loughborough, \\ Leicestershire, UK
}

\section{Paul Hughes}

School of Business and Economics, Loughborough University, Loughborough, Leicestershire, UK

\section{Mathew Hughes}

Nottingham University Business School, University of Nottingham, Nottingham, UK

This is an Author's Original Manuscript of an article whose final and definitive form, the Version of Record, has been published in the Journal of Marketing Management 2012 [copyright Taylor \& Francis], available online at: http://www.tandfonline.com/doi/abs/10.1080/0267257X.2011.645857 


\begin{abstract}
This paper examines the moderating effects of market orientation's intelligence generation and dissemination components on the response-performance relationship. We offer valuable insight into the application of, and subsequent returns to, market orientation in the public leisure sector, thereby helping to broaden the appeal, relevance and usefulness of this important marketing theory to other contexts. The research involved a national survey questionnaire to 1,060 public leisure managers of local government leisure facilities in England. Empirical testing through structural equation modelling revealed two important findings. Firstly, intelligence generation efforts of the organisation can in part affect the performance returns to an organisation from its responsiveness to market intelligence. Secondly, intelligence generation coupled with organisation-wide dissemination of intelligence can have a destructive impact on the response-performance relationship, demonstrated by a negative significant moderating impact on this relationship. This paper provides an alternative explanation to the deployment of market orientation as a means to create value and an explanation that transcends its current linear portrayal in public service delivery.
\end{abstract}

Key words - market orientation; intelligence response; public sector; service providers; service performance; survey questionnaire 


\section{Introduction}

Market orientation remains the central, most compelling and most persistent pillar of contemporary marketing thought. In extolling the virtues of market orientation, Atuahene-Gima, Slater, and Olson (2005) specify that '[i]t is almost axiomatic that through ongoing monitoring of customers, their needs, and market conditions, firms adapt to develop and deliver the products and services that are valued by customers' (p. 646). Still, market orientation is not without its critics. A systematic increase in the risk of market myopia, inertia and slow response to change are typically the most common charges levelled (Grewal \& Tansuhaj, 2001).

Such criticism has led to several recent efforts to refine our knowledge of how market orientation might create value for organisations. Cadogan, Kuivalainen, and Sundqvist (2009) consider the relationship between the degree of market orientation and performance; Morgan, Vorhies, and Mason (2009) assess the role of marketing capabilities in extracting performance improvements from market orientation; AtuaheneGima et al. (2005) point to differences between a reactive and proactive market orientation; Zhou, Yim, and Tse (2005) examine interactions between market orientation and other strategic orientations; Matsuno, Mentzer, and Özsomer (2002) analyse the returns to market orientation when a firm is entrepreneurially oriented; and Grewal and Tansuhaj (2001) evaluate the problems posed by market orientation when firms face complex operating circumstances. Central to these studies is an assessment of the deployment of market orientation above mere possession.

Despite such efforts, however, two persistent and important gaps in our understanding of market orientation exist, and these gaps emerge directly from the 
insufficient study of its context and deployment. First, studies tend to assume that organisations which collect, disseminate organisation-wide, and respond to market intelligence in turn will accrue returns to performance. This line of argument highlights the failure of the linear characterisation of the market orientation-performance relationship to account for the complexity of its deployment. In response, it is posited that the intelligence generation and dissemination components of market orientation in fact moderate the response-performance relationship, offering a different model of the deployment of market orientation than currently espoused in the literature.

Second, studying marketing principles in the public leisure sector is essential to test the robustness of the linear portrayal of the market orientation construct and to generate knowledge to more effectively manage public leisure services. The vast majority of market orientation research relates to private sector firms but in doing so, studies ignore the relevance of the construct to public sector organisations. Recent attempts to address this void have reported favourable returns to such organisations. Lindsay and Murphy (1996), Siu and Wilson (1998), Vázquez, Alvarez, and Santos (2002), Macedo and Pinho (2006), White and Simas (2008), and Dolnicar and Lazarevski (2009) have all reported market orientation should improve the performance of non-profit or public sector organisations.

The contribution from this study is two-fold. First, and to the best of our knowledge, we are the first to study the moderating effects of market orientation’s intelligence generation and dissemination components on the response-performance relationship. In doing so, we offer an alternative explanation of the deployment of market orientation as a means to create value, and an explanation that transcends its current 
portrayal. Second, by focusing on the public leisure sector in England, where managing the needs of service users is essential, we offer valuable insight into the deployment of, and subsequent returns to, market orientation in public service provision. In doing so, we help to broaden the appeal, relevance and usefulness of this important marketing theory to other contexts.

\section{The deployment of market orientation}

Market orientation can be defined as the set of activities processes and behaviours derived from the implementation of the marketing concept (Gonzalez-Benito, GonzalezBenito, \& Munoz-Gallego, 2009). Accordingly, Kohli and Jaworski (1990) provide a behavioural perspective of market orientation. They present an operational definition of market orientation as '...the organisation-wide generation of market intelligence pertaining to current and future customer needs, dissemination of the intelligence across departments, and organisation-wide responsiveness to it’ (Kohli \& Jaworski, 1990, p. 6). Market intelligence is a broad concept which includes a consideration of exogenous market factors which affect customer needs and performance, and current as well as future needs of customers.

Market orientation is an organisation-wide prescription requiring the whole organisation to be organised and coordinated in the service of the customer, with a view to providing the organisation with long-term direction (Caruana, Ramaseshan, \& Ewing, 1999). Accordingly, most interpretations of market orientation have an operative focus, by which each behavioural activity is prescribed and its deployment follows an 
incremental and linear process, starting with intelligence generation (Kohli \& Jaworski, 1990).

The relationship between market orientation and performance has been explored at depth by means of different methodologies, contexts and measures. A large body of research indicates that positive linkages exist between market orientation and performance (Nelson \& Henderson, 2005; Matsuno \& Mentzer, 2000; Slater \& Narver, 2000; Jaworski \& Kohli, 1993). Issues of judgement and perception, however, have been raised as important considerations in market orientation research (Noble et al., 2002). For example, Wilson (1996) and Jaworski and Kohli (1993) find significant relationships when using a perceptual assessment of performance, but this link is not present when related to items such as market share (Jaworski \& Kohli, 1993). Further, empirical findings by Ho and Huang (2007), Han et al. (1998) and Diamantopoulos and Hart (1993) have produced results that are unsupportive and even detect a negative relationship. While Cadogan et al. (2009) predict that the relationship found between market orientation and business performance is an inverted $U$ shape, such that high levels of market orientation may reduce performance. In addition, various contributions support a positive relationship but disagree about the market orientation and performance dimensions involved, as well as the intensity of the relationship (Gonzalez-Benito et al., 2009). These varying outcomes provide equivocal evidence regarding if and when market orientation has a positive direct effect on performance (Silva, Moutinho, Coelho, \& Marques, 2009). To this end, Noble, Sinha, and Kumar (2002) contend that the fundamental link between market orientation and performance has yet to be fully explored. 
Past empirical research has focused on a linear relationship between market orientation and performance (Hult \& Ketchen, 2001). But the equivocal nature of the direct performance impact of market orientation has driven researchers to look for moderating effects (Langerak, 2003). As the conceptual network surrounding market orientation has been explored, several factors potentially acting as moderators have been identified. Several researchers have empirically investigated the moderating effect of market-level (e.g., market turbulence, technological turbulence and competitive intensity) and firm-specific (e.g., strategy type) factors on the relationship between market orientation and business performance (Langerak, 2003). However, investigators have overlooked the moderating effects of the individual activities of the market orientation construct. Rather, studies assume that market orientation has a simple, linear shape. The separate analysis of each component of market orientation can provide additional insights into its nature and role within firms (Gonzalez-Benito et al., 2009). Responsiveness and performance outcomes share a direct relationship, such that unless an organisation takes action in response to intelligence, neither the acquisition nor the dissemination of intelligence will result in externally-oriented actions that can lead to success (Homburg, Krohmer, \& Workman, 2004). However, the effects of intelligence generation and organisation-wide intelligence dissemination are less clear.

At present, market orientation theory rightly specifies that intelligence generated through market-facing activities help inform the organisation in a way that triggers response (Kohli \& Jaworski, 1990). However, intelligence generation activities also create the reservoir of knowledge that must ultimately be used to inform, shape and implement one form of response over another. The higher the quality and quantity of 
information available, the better the response of the organisation should be (Souchon, Cadogan, Procter, \& Dewsnap, 2004). This development of new knowledge or insights have the potential to direct behaviour (Slater \& Narver, 1995) and as such, provides a means to improve resource responsiveness and as a natural consequence, the provision of service. Organisation-wide intelligence dissemination, however, might compromise the interface between responsiveness, performance and intelligence generation. An organisation skilled at intelligence generation will be able to create and acquire large amounts of information rapidly and near continuously. But sharing this wealth of information organisation-wide can overload decision-makers' capacity to intake and interpret the information to make appropriate decisions (Souchon et al., 2004; Vyas \& Souchon, 2003). As strategic marketing issues become clouded in the sea of information made available to decision-makers, the compromised responses that follow can inflict damage on performance (Cho \& Hambrick, 2006; Ocasio, 1997).

Blackman and Lee-Kelley (2006) advanced the view that the prevention of knowledge acquisition and its sharing can cause stagnation that in turn would be expected to undermine organisational response to emerging market opportunities and threats. From this point of view one might argue that response formation requires more data and information to justify an emerging response. However, Lee-Kelley, Blackman and Hurst (2007) posited that the "usefulness” of an individual 'knowledge worker' (or in our instance a 'decision-maker') to the organisation they are a member of is dictated by his or her "ability (and willingness) to "utilise, share and synthesise existing knowledge to create new ideas” (p.205). As our emphasis is on the organisation level, we would suggest that the organisational process to generate, share and enable synthesis of market 
intelligence in part contributes to the inability to effectively synthesise and use such intelligence if the processing capacity of the individual is overloaded. The studies of Ocasio (1997), Souchon et al. (2004) and Vyas and Souchon (2003) among others help explain why the translation of intelligence into new ideas to respond to market change, wants, opportunities or threats might not necessarily happen in the manner Lee-Kelley et al. (2007) prescribe.

A further explanation for a potential breakdown in market orientation's performance consequences stems from Deshpande, Farley and Webster's (1993) work on organisational culture. Deshpande and Webster (1989) define organisational culture as 'the pattern of shared values and beliefs that help individuals understand organizational functioning and thus provide them with the norms for behavior in the organization' (p.4). Deshpande et al. (1993) focus their attention on an organisational cognition paradigm of organisational culture (see also Deshpande \& Webster, 1989). The cognitive perspective of organisational culture focuses on managerial information processing, viewing organisations as knowledge systems (Deshpande et al., 1993). Deshpande et al. (1993) argue that such a view of culture is helpful because a market orientation is essentially an organisational information processing approach (Kohli and Jaworski, 1990). In turn, cultures that complicate the flow of information and decision-makers' ability to harness that information (cf., Lee-Kelley et al., 2007) would likely experience difficulties in converting generated intelligence into intelligent and effective market responses (Deshpande et al., 1993).

In summary then, theory leads to the conclusion that the intelligence generation and organisation-wide intelligence dissemination components of market orientation might 
moderate the responsiveness-performance relationship. We subsequently seek to examine the deployment of market orientation, beyond its current linear portrayal, as a means to create value in the public leisure sector.

\section{The public leisure sector}

The environment in which public sector organisations operate is becoming ever more volatile, with such organisations increasingly facing the dual pressures of growing customer expectations (Laffin \& Liddle, 2006) coupled with the same economic pressures to survive as private sector organisations (Clohesy, 2003), particularly within the current local government environment of budget cuts (Berg, Barry, \& Chandler, 2008). Therefore public sector organisations are facing growing pressure to provide more effective, efficient and flexible ways of serving their constituencies (Caemmerer \& Banerjee, 2009). One common response has been for public leisure providers to mimic their private sector counterparts by introducing a range of market-based reforms, intended to improve their efficiency and the value that they offer to their customers (Johanson, 2009; Heracleous \& Johnston, 2009). Indeed, strategic marketing principles, typical of the private sector, are increasingly being transferred to the public leisure context (e.g., Kaczynski, 2008). Therefore, it can be argued that marketing principles of the private sector may well be relevant to the performance of public leisure facilities and is worthy of investigation. Performance in this context, then, represents a concern for meeting increasing customer expectations (customer performance) while simultaneously securing economic survival (business performance), in light of budgetary reductions in the public leisure sector. 
Butler and Collins (2002) assert that the broad principles of the marketing concept are applicable in the public sector, including existing conceptualisations, frameworks and models which can be suitably adapted for the operating environment of public sector organisations. By basing our examination of the deployment of market orientation in the public leisure sector, we respond to calls for a model of market orientation in public service provision to address challenges posed by increasing customer expectations of public services (Cervera, Molla, \& Sanchez, 2001; Macedo \& Pinho, 2006), while attending to the need for economic survival in the current local government environment of budget cuts (Berg et al., 2008). Extant marketing research suggests that the adoption of a market orientation by local government in the delivery of public leisure services facilitates the provision of better services suitable to citizens' demands (Lindsay \& Murphy, 1996; Siu \& Wilson, 1998; Vázquez et al., 2002; Macedo \& Pinho, 2006; White \& Simas, 2008; Dolnicar \& Lazarevski, 2009). Arguably, market orientation can therefore provide public services with suitable instruments to acquire knowledge of public needs and help develop service delivery to better satisfy those needs (Cervera et al., 2001; Jaw, Lo, \& Lin, 2010). We extend this charge by studying marketing principles in the public leisure sector to test the robustness of the linear portrayal of the market orientation construct and to generate further knowledge and insight as to how the deployment of market orientation can benefit the business and customer performance of public leisure services.

Consistent with Shoham, Ruvio, Vigoda-Gadot, and Schwabsky (2006) we now form our study hypotheses in light of the current empirical knowledge about the 
relationship between market orientation and performance in for-profit organisations with expectations that this knowledge is transferable to the public leisure sector.

\section{Hypotheses}

Unless an organisation responds to the market intelligence it collects and generates, then ultimately very little is accomplished (Kohli \& Jaworski, 1990). However, it is not the act of response itself that can add to performance but rather the organisation's responsiveness to the market intelligence. The speed and coordination with which market intelligence is responded to dictates whether the organisation responds faster than its competitors and in a manner timelier to its customers (Kohli, Jaworski, \& Kumar, 1993). In turn, studies have shown that timely responses to customer- and competitor-related changes benefit organisations (Homburg et al., 2007).

An organisation’s competence at designing and implementing market responses from its market intelligence is a second component of effective responsiveness (Kohli et al., 1993). The design and implementation of marketing responses entail the development or improvement of the organisation's competitive positioning and product-service offering (Souchon et al., 2004). An organisation more adept at these activities should reap rewards in terms of business and customer performance because the organisation's responsiveness to market intelligence becomes better grounded to meet the needs of the evolving market more effectively (Narver \& Slater, 1990). Accordingly:

Hypothesis 1: Responsiveness to market intelligence benefits both business performance $\left(\mathrm{H}_{1 \mathrm{a}}\right)$ and customer performance $\left(\mathrm{H}_{1 \mathrm{~b}}\right)$. 
Kohli and Jaworski (1990) associated responsiveness to information use. Responsiveness to marketing information involves two activities, namely, response design and response implementation, both coordinated in time to ensure a timely response. However, if the design and implementation of marketing responses entail the revision of competitive positioning and the revision of product-service offerings, then the collection and generation of sufficient marketing information ought to affect the responsiveness-performance relationship (Souchon et al., 2004). Specifically, organisations that constantly monitor emerging trends in the environment along with customer needs, and collect greater amounts of intelligence on the market accordingly, can ultimately develop responses based on this increased understanding, in principle (Atuahene-Gima \& Ko, 2001). Greater amounts of market intelligence can then increase the scope, accuracy and relevance of response to current market conditions.

The generation of market intelligence relies on a variety of individuals across functional departments throughout the organisation collectively monitoring market trends, customer information and competitor activity to acquire market knowledge that is relevant and timely to the organisation's operations. A greater number of intelligence generation mechanisms and a greater number of intelligence harvesting activities should result in a reduction in the probability of important information being missed (Cadogan, Souchon, \& Procter, 2008). Superior mechanisms and activities to generate intelligence improve the information base that feeds into the response initiatives of the organisation. Given that the majority of marketing response strategies are implemented in an emergent and improvised manner (Sashittal \& Jassawalla, 2001), greater quantities of generated 
market intelligence ought to improve the organisation's responsiveness to market change and the performance effects of its responses, as more intelligence enables the organisation to make real-time changes to its responses (Moorman \& Miner, 1998). Moorman and Miner (1998) refer to the 'logic of responsiveness', arguing that organisations sometimes face unexpected or ad-hoc jolts or market surprises that make prior plans irrelevant or incomplete in important ways. Effective market orientation then depends on organisations having processes for effectively collecting market intelligence about customers and competitors and then integrating this intelligence into the strategic decision-making processes (responses) of the organisation in an emergent and real-time manner (Hult \& Ketchen, 2001). Thus:

Hypothesis 2: Intelligence generation positively moderates the relationship between responsiveness and business performance $\left(\mathrm{H}_{2 \mathrm{a}}\right)$ and customer performance $\left(\mathrm{H}_{2 b}\right)$.

Hypothesis 2 notwithstanding, and based on our previous discussion, it might not necessarily be the case that the effect of intelligence generation on response is as clear cut. The link between responsiveness to market intelligence and organisational performance when accounting for intelligence generation is likely to be further moderated by organisation-wide intelligence dissemination. At the heart of this proposition lie the concepts of bounded rationality, information overload and the degree of dissemination. Bounded rationality implies that decision-makers' ability to make superior decisions is constrained by the information they have (intelligence generation) but also their cognitive limits to process vast quantities of information within a finite amount of time (Cyert \& 
March, 1963; Dickson, 1992). Souchon et al. (2004) found a positive relationship between the instrumental and conceptual use of information and responsiveness, but also found that this relationship was moderated by information overload. Accordingly, when information overload is absent or low, the relationship between intelligence generation and its use for organisational responsiveness is positive. As information overload increases, however, the link becomes negative. Therefore, an organisation's ability to respond timely and effectively is influenced by information overload, a situation that can emerge as the organisation becomes increasingly superior at intelligence generation and the organisation-wide dissemination of that intelligence.

As an organisation increases its intelligence generation and its organisation-wide dissemination of that intelligence, employees and decision-makers face information overload (Bardin \& Majer, 1983). Market orientation can slow down response in complex operating circumstances because as a learning process focused on all aspects of an organisation's environment, the intelligence generation effort can bombard employees and decision-makers with information that overloads their capacity to process the information correctly, appropriately and in a timely manner (Grewal \& Tansuhaj, 2001). When shared organisation-wide, the sheer quantity of information can also overload the capacity of employees and decision-makers to respond to the information in a timely manner and in a way that allows them to use it meaningfully. This problem is caused by the bounded rationality of employees and decision-makers (Cyert \& March, 1963; Dickson, 1992) as when managers are confronted with far more ambiguous and complex information than they can handle, they will fall back on their experiences, preferences, and other biases to deal with the barrage (Cho \& Hambrick, 2006). 
The quality of decision-making can be adversely affected when an excess amount of information is presented to the decision-maker (Souchon et al., 2004). Studies report a wealth of damaging consequences in such circumstances. For example, managerial attention to urgent market matters becomes clouded leading decision-makers to react to more straightforward problems with more straightforward solutions (Vyas \& Souchon, 2003). Thus, instead of reacting to environmental changes requiring urgent managerial attention, overloaded decision-makers may deliberately or unconsciously compromise the decision-making process (Cho \& Hambrick, 2006). Moreover, when overloaded with information and faced with ever increasing quantities of intelligence, the decision-maker cannot direct sufficient attention to interpret and sift the information to identify priorities and best responses. The effect is compromise in the design and execution of responses to market change (Glazer et al., 1992; Souchon et al., 2004).

These problems are best captured by Ocasio’s (1997) attention-based theory, arguing that 'what decision-makers do depends on what issues and answers they focus their attention on’ (p. 188). Ocasio (1997) further argued that how decision-makers notice, encode, interpret and focus time and effort on issues and answers that emerge from intelligence generation efforts is affected by how the person chooses to manage the information presented to them given their bounded rationality. In essence, the responses of decision-makers are unlikely to be optimal because these decision-makers are forced to filter the abundance of information that confronts them (Ocasio, 1997). It is this filtration process that can distort responsiveness in the manner put forward by Glazer, Steckel, and Winer (1992), Souchon et al. (2004), and Vyas and Souchon (2003) among others. 
A decision-maker's usefulness is dictated by their ability to utilise, share and synthesise existing knowledge to create new ideas (Lee-Kelley et al., 2007). When this individual ability is complicated by organisational processes that generate and share an increasingly large amount of market intelligence, the individual is likely to experience an inability to effectively synthesise and use such intelligence owing to the processing capacity of the individual being overloaded (Ocasio, 1997; Souchon et al., 2004; Vyas \& Souchon, 2003).

Based on this discussion we posit that dissemination provides a further moderating effect on the moderating relationship between intelligence generation and the response-performance relationship by increasing the degree of information flow to decision-makers. Considerable intelligence generation combine with rapid and broad dissemination of that intelligence risks increasing the information flow to such an extent that the decision-maker is overloaded with an amount of information too excessive to process effectively or to response to optimally (Cho \& Hambrick, 2006; Glazer et al., 1992; Ocasio, 1997; Souchon et al., 2004; Vyas \& Souchon, 2003). Thus:

Hypothesis 3: Intelligence generation and organisation-wide dissemination together negatively moderate the relationship between responsiveness and business performance $\left(\mathrm{H}_{3 \mathrm{a}}\right)$ and customer performance $\left(\mathrm{H}_{3 \mathrm{~b}}\right)$.

\section{Research methodology}

\section{Data generation}


In this study a public leisure provider refers to a publicly-owned site with at least one of the following facilities; health and fitness suite, swimming pool, or sports hall, where at least one is available to members of the general public on a pay and play or membership basis. The total population is 1,060 public leisure service providers and using a mail survey approach, 1,060 questionnaires were sent to public leisure facility managers nationally across England. The survey instrument follows the recommendations, directions, and principles of good questionnaire development practice as set forth by Dillman (2007). This involves pre-notification; mailing of a full questionnaire pack; first reminder letter; and second reminder consisting of a full questionnaire pack, and includes recommendations regarding cover letter, questionnaire salience and length, return postage, follow-ups, anonymity, lack of explicit deadlines, and university sponsorship. 280 responses were subsequently received but 5 of these were unusable due to missing data, thus forming an overall response rate of 26 percent.

\section{Measures}

Organisations differ in the extent to which they generate and disseminate market intelligence internally, and take action based on that intelligence. Therefore, Kohli and Jaworski (1990) conceptualise the market orientation of an organisation as one of degree. The MARKOR scale, developed and validated by Kohli et al. (1993) is a suitable tool for measuring market orientation and is commonly used in marketing research (Homburg et al., 2004). Consistent with Laing (2003), we suggest that there is no need for a fundamental redefinition of the market orientation construct, but simply a need to acknowledge and reflect the specific context and characteristics of public services. This is 
underpinned by the contention that ' ...there are very few inherently public services, as evidenced by the creeping privatisation of many such public services, raising the question of whether in fact many public services can be viewed as fundamentally different or unique’ (Laing, 2003: p. 430). Kohli et al. (1993) describe a number of shortcomings of their own scale, suggesting that it may be too long and consist of items relating to specific activities that may not be generalisable to public and not-for-profit industries. Thus, this study adopts a modified version of this scale. MARKOR scale items referring to different departments, which relate to specific organisational activities and structure that are consistent with private sector organisations but are not generalisable to public leisure service providers, were excluded from the final measurement scale used (e.g., 'There is minimal communication between marketing and manufacturing departments concerning market developments'; 'Several departments get together periodically to plan a response to changes taking place in our business environment'; 'The activities of the different departments in this business unit are well coordinated'). In addition to these items, a single adapted item from Vazquez et al. (2002) is included with the MARKOR intelligence generation items as it addresses the wider stakeholders engaged in public service delivery (e.g., 'We gather data from our sector for use in the developmental plans for our activities.'). Public leisure managers were deemed key informants since such individuals formalise their knowledge of local competitive conditions to devise appropriate strategic responses (Benson \& Henderson, 2005).

In accordance with Chakravarthy (1986), a multi-factor model of performance assessment is used whereby performance has two components: first, four business performance items were adapted from Delaney and Huselid (1996), the items adopted 
place emphasis on financial performance, specifically new customer sales, profitability, market share and marketing, which refers to the ability to refine organisation activities now and into the future which can generate significant benefits in the form of sustainably superior performance (Cockburn, Henderson, \& Stern, 2000). Therefore, since the items focus on economic outcomes (Delaney \& Huselid, 1996) it was deemed appropriate to combine the four measures into a single dependent variable termed business performance. Second, four customer performance items, which comprise perceptual measures of customer satisfaction and customer value adapted from Krohmer, Homburg, and Workman (2002), and quality of services and development of services measures adapted from Delaney and Huselid (1996). Together these variables provide a broad assessment of perceptions of customer performance from an organisational perspective. Public leisure managers are considered outward-facing owing to their close interface with customers, the perceptual measures adopted were therefore deemed appropriate. Consistent with Delaney and Huselid (1996) and Krohmer et al. (2002), the performance measures employed are relative, or benchmarked, in the sense that they are derived from questions asking informants to assess organisational performance (e.g., business and customer performance) relative to the performance of competing facilities, which provided an appropriate frame of reference. For example, competition is an essential management tool in public services via the use of benchmarking to compare relative performance across public service providers and in the requirement to achieve continuous improvement (Coalter, 2000). In addition, the inclusion of perceptual measures enables an analysis of the organisational performance of public leisure service providers as specific objective data for these organisations is generally unavailable (Krohmer et al., 
2002). Moreover, research has found measures of perceived performance to correlate positively with objective measures of performance, which supports their validity (Delaney \& Huselid, 1996; Krohmer et al., 2002).

Content and face validity was established on the basis of expert judgement. Content validity was determined by distributing the questionnaire to several academics that had substantial knowledge of the literature from which the constructs were derived. Consequently, being able to comment on the degree to which the measures used capture the aforementioned constructs. Similarly, distributing the questionnaire to several public leisure managers, with the objective to ensure that the measures employed were appropriately worded and understood by the respondents, assessed face validity. To ensure the accuracy of responses, feedback given by academics and public leisure managers on the measures employed was used to enhance and modify the research questionnaire. Therefore, the content and face validity of the measures contained within the questionnaire was established.

A 7-point Likert-type scale was adopted for all items. Market orientation scales were ranked from (1) strongly disagree to (7) strongly agree. Performance measures were scaled as (1) very poor to (7) excellent when comparing performance over the past 3 years to that of other competing fitness suites. The precise wording of measurement items pertaining to measures of market orientation and performance are presented in Table 1, along with the properties of these measurement items as derived through confirmatory factor analysis (CFA). All factor loadings are acceptable and the CFA results are as follows: $\chi^{2}=238.07$; degrees of freedom $(\mathrm{df})=94 ; \chi^{2} / \mathrm{df}=2.53$; Root Mean Square Error of Approximation $($ RMSEA $)=.08$; Goodness of Fit Index $(\mathrm{GFI})=.90$; Comparative Fit 
Index $(\mathrm{CFI})=.96 ;$ Incremental Fit Index $(\mathrm{IFI})=.96 ;$ Non-Normed Fit Index $(\mathrm{NNFI})=$ .94. These results reflect a strong confirmatory model with acceptable model fit and indicate good measurement item properties. One aspect of contention may be the relative chi-square measure $\chi^{2} / \mathrm{df}$. While some researchers argue that a ratio of less than $2: 1$ is necessary, Carmines and McIver (1981) state that relative chi-square should be in the 2:1 or 3:1 range for an acceptable model, whereas Kline (1998) says 3 or less is acceptable. Consequently, it is contended that the CFA results demonstrate acceptable model fit.

Table 2 displays the descriptive statistics, composite reliabilities (CR) and average variance extracted (AVE) for all constructs. All CR coefficients were above the acceptable minimum threshold of .60 (Bagozzi and Yi, 1988), ranging from .60 to .83, thereby enhancing our claim for convergent validity and model reliability. AVE ranged between .34 and .61. Although it is preferable for AVE to exceed .50 (Bagozzi and Yi, 1988), previous marketing research have included many constructs with AVE below this ideal (e.g., Atuahene-Gima and Murray, 2004). Whilst this is accepted in previous marketing research at the highest level, the work of Barclay, Thompson, and Higgins (1995), Fornell and Larcker (1981), Hughes, Hughes, and Morgan (2010), Kim and Atuahene-Gima (2010) and Kohli, Shervani, and Challagalla (1998) indicate that a more thorough test to determine whether AVE vales are acceptable is to examine the square root of AVE for each construct across all other constructs in the correlation matrix. The square root values should be greater than the correlation between the constructs. Where this is the case, it demonstrates that (a) the AVE values are acceptable and (b) there is discriminant validity between the constructs. Thus, to ensure that the AVE values are acceptable, the square root of AVE for each construct was calculated and is shown on the 
diagonal of the correlation matrix (Table 2). As these values exceed those of the offdiagonal elements, discriminant validity can now also be claimed. Consequently, it is concluded that the measures exhibit good measurement properties.

A single source self-report questionnaire was used to generate data in this study and a drawback of this approach is that common method bias may underlie the data. In developing the instrument, the directions of Spector and Brannick (1995) for limiting this bias were followed: the measurement scales were placed in random order; non-idealised responses and wording neutrality were adopted; questionnaire length was reduced (3 pages); and detailed instructions for its completion were provided. Common method bias was examined for using the Harman one-factor test (Podsakoff, MacKenzie, Lee, \& Podsakoff, 2003) consistent with other works in marketing (e.g., Hughes, Morgan, \& Kouropalatis, 2008). All variables were specified in a single factor CFA. If common method bias is present and represents a problem, then a single factor will fit the data well. The results reveal that this was not the case: $\chi^{2}=869.48 ; \mathrm{df}=104 ; \chi^{2} / \mathrm{df}=8.36$; RMSEA $=.16 ; \mathrm{GFI}=.72 ; \mathrm{CFI}=.81 ; \mathrm{IFI}=.81 ; \mathrm{NNFI}=.78$. The $\chi^{2} / \mathrm{df}$ ratio exceeds the cut-offs suggested by Bollen (1989), Carmines and McIver (1981), and Kline (1998) and the RMSEA far exceeds the acceptable cut-off recommended by Browne and Cudeck (1992) and Hu and Bentler (1999). The model fit statistics of GFI, CFI, IFI, and NNFI also show significant problems with a single factor solution and demand rejection of this model $(\mathrm{Hu}$ and Bentler, 1999). It is concluded that common method bias is not a problem within our data (Podsakoff et al., 2003). 


\begin{tabular}{|c|c|c|c|}
\hline Construct & Measurement Item & $\begin{array}{c}\text { Standardised } \\
\text { Factor } \\
\text { Loading }\end{array}$ & $\begin{array}{c}t- \\
\text { value }\end{array}$ \\
\hline $\begin{array}{r}\text { Intelligence } \\
\text { Generation }\end{array}$ & $\begin{array}{l}\text { We formally consult customers at least once a } \\
\text { year to find out what products or services they } \\
\text { will need in the future. } \\
\text { We gather data from our sector for use in the } \\
\text { developmental plans for our activities. } \\
\text { We survey customers at least once a year to } \\
\text { assess the quality of our products and services. }\end{array}$ & $\begin{array}{l}.85 \\
.70 \\
.79\end{array}$ & $\begin{array}{l}11.39 \\
12.48\end{array}$ \\
\hline $\begin{array}{l}\text { Intelligence } \\
\text { Dissemination }\end{array}$ & $\begin{array}{l}\text { We have meetings at least once a quarter to } \\
\text { discuss market trends and developments. }\end{array}$ & .66 & $-^{\dagger}$ \\
\hline & $\begin{array}{l}\text { Our leisure facility periodically circulates } \\
\text { documents (e.g., reports, newsletters) that } \\
\text { provide information on our customers. }\end{array}$ & .65 & 5.86 \\
\hline Responsiveness & $\begin{array}{l}\text { For one reason or another we tend to ignore } \\
\text { changes in our customers' service needs. (R) } \\
\text { We periodically review our service } \\
\text { development efforts to ensure that they are in } \\
\text { line with what customers want. } \\
\text { Even if we came up with a great marketing } \\
\text { plan, we probably would not be able to } \\
\text { implement it in a timely fashion. (R) }\end{array}$ & $\begin{array}{l}.60 \\
.53 \\
.62\end{array}$ & $\begin{array}{l}-^{\dagger} \\
6.49 \\
7.15\end{array}$ \\
\hline $\begin{array}{l}\text { Business } \\
\text { Performance }\end{array}$ & $\begin{array}{l}\text { Attracting new customers. } \\
\text { Marketing. } \\
\text { Profitability. } \\
\text { Market share. }\end{array}$ & $\begin{array}{l}.75 \\
.69 \\
.76 \\
.71\end{array}$ & $\begin{array}{l}-^{\dagger} \\
10.67 \\
11.56 \\
10.92\end{array}$ \\
\hline $\begin{array}{l}\text { Customer } \\
\text { Performance }\end{array}$ & $\begin{array}{l}\text { Achieving customer satisfaction. } \\
\text { Providing value for customers. } \\
\text { Quality of services. } \\
\text { Development of services. }\end{array}$ & $\begin{array}{l}.73 \\
.69 \\
.80 \\
.72\end{array}$ & $\begin{array}{l}-^{\dagger} \\
10.49 \\
11.91 \\
10.90\end{array}$ \\
\hline
\end{tabular}

†Item fixed to set the scale.

(R) Item reverse-coded

TABLE 2

Descriptive Statistics and Construct Robustness

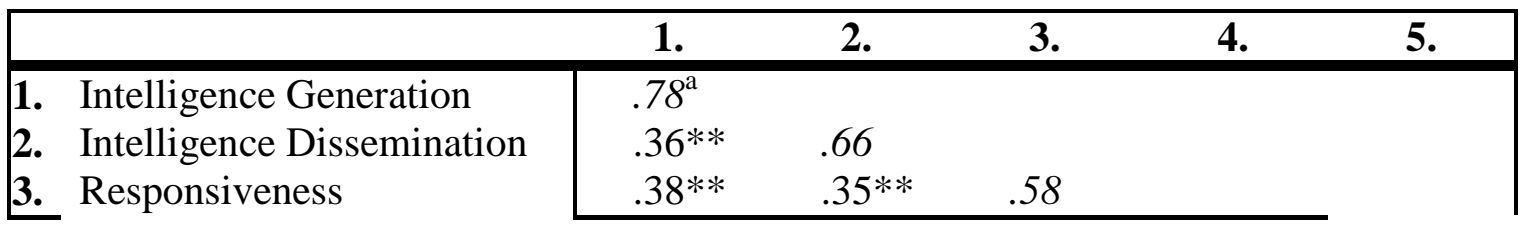




\begin{tabular}{|l|rrrrr|}
\cline { 2 - 5 } 4. Business Performance & $.26^{* *}$ & $.33^{* *}$ & $.44^{* *}$ & .73 & \\
5. Customer Performance & $.22^{* *}$ & $.22^{* *}$ & $.48^{* *}$ & $.55^{* *}$ & .74 \\
CR & & & & & \\
AVE & .83 & .60 & .61 & .82 & .83 \\
Mean & .61 & .43 & .34 & .53 & .55 \\
SD & 5.70 & 4.78 & 5.22 & 4.69 & 5.32 \\
& 1.27 & 1.52 & 1.14 & 1.05 & .93 \\
\hline$* \mathrm{p}^{*}<01$ & & & & & \\
\hline
\end{tabular}

$* * \mathrm{p}<.01$.

CR: Composite reliability.

AVE: Average variance extracted.

SD: Standard deviation.

a Figures on the diagonal are square roots of AVE.

\section{Analysis and results}

Structural equation modelling was employed to test the research hypotheses using LISREL 8.8. Ping's (1995) protocol for estimating and evaluating structural models with interaction terms was used to test our hypotheses, and the latent variables involved in interaction terms were mean-centred to avoid potential multicollinearity problems (Bollen, 1989). The maximum likelihood procedure was employed and given the need to examine interaction terms, two models were specified: the restricted model and an unrestricted model. Both models contain all data and hypotheses but the paths linking the interactions terms to both forms of performance are fixed at zero in the restricted model, whilst these paths are freely estimated in the unrestricted model. For the interaction term analysis to be appropriate the unrestricted model must be superior to the restricted model. The model fit statistics for the restricted model are as follows: $\chi^{2}=174.30 ; \mathrm{df}=62 ; \chi^{2} / \mathrm{df}$ $=2.81 ;$ RMSEA $=.08 ;$ GFI $=.91 ;$ CFI $=.95 ;$ IFI $=.95 ;$ NNFI $=.94$. For the unrestricted model: $\chi^{2}=155.10 ; \mathrm{df}=58 ; \chi^{2} / \mathrm{df}=2.67 ; \mathrm{RMSEA}=.08 ; \mathrm{GFI}=.92 ; \mathrm{CFI}=.96 ; \mathrm{IFI}=.96$; NNFI $=.94$. A significant change in chi-square indicates that the unrestricted model is superior. In this case, $\Delta \chi^{2}(\mathrm{df})=19.18(4)$ is significant at $p \leq .01$ indicating that the 
unrestricted model is superior and is thus adopted for hypothesis testing. These statistics taken together with the measurement item properties examined previously and the lack of evidence for common method bias indicate that the model, measurement items, latent constructs and the upcoming results are very much acceptable.

The results (Table 3) demonstrate complete support for $\mathrm{H}_{1}$ in that timely responsiveness to intelligence, benefits both business performance $\left(\mathrm{H}_{1 \mathrm{a}}\right)(.84 ; p \leq .01)$ and customer performance $\left(\mathrm{H}_{1 \mathrm{~b}}\right)(.90 ; p \leq .01)$. Consideration of intelligence generation as a moderator of this relationship reveals that intelligence generation does positively moderate the relationship between responsiveness and customer performance $\left(\mathrm{H}_{2 \mathrm{~b}}\right)(.19$; $p \leq .05$ ) but no significant relationship is found between this and business performance, thus providing no support for $\mathrm{H}_{2 \mathrm{a}}(.08$; ns). Hypothesis 3 asserted that intelligence generation and dissemination together would negatively moderate the relationship between responsiveness and performance. This assertion is fully supported in the results whereby this moderating relationship is negatively related to both business performance $(-.17 ; p \leq .05)$ and customer performance $(-.16 ; p \leq .05)$

TABLE 3

Structural Equation Modeling Results ${ }^{\mathrm{a}}$

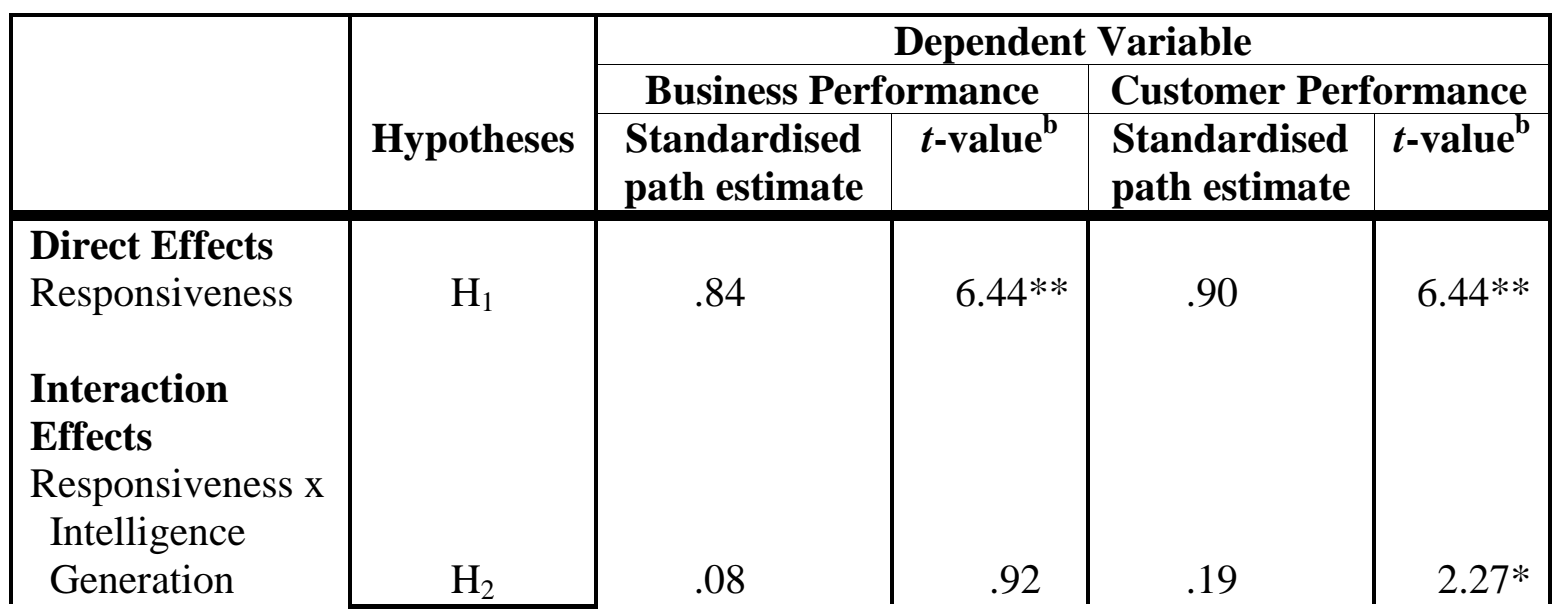




\begin{tabular}{|c|c|c|c|c|c|}
\hline $\begin{array}{l}\text { Responsiveness x } \\
\text { Intelligence } \\
\text { Generation x } \\
\text { Intelligence } \\
\text { Dissemination }\end{array}$ & $\mathrm{H}_{3}$ & -.17 & $-2.01 *$ & -.16 & $-1.94^{*}$ \\
\hline $\begin{array}{l}\text { Squared Multiple C } \\
\text { Reduced Form }\end{array}$ & ions for & \multicolumn{2}{|c|}{.60} & \multicolumn{2}{|c|}{.68} \\
\hline
\end{tabular}

${ }^{a}$ Results from single structural equation model (the unrestricted model).

${ }^{\mathrm{b}}$ Critical t-values: when ${ }^{* *} p=.01$, critical t-value $=2.326$; when ${ }^{*} p=.05$, critical t-value $=1.645$.

\section{Discussion, conclusions, and limitations}

The objective of this study was to re-examine the deployment of market orientation in the public leisure sector. Our contribution to marketing theory is two-fold. First, and to the best of our knowledge, we are the first to study the moderating effects of market orientation's intelligence generation and dissemination components on the response-performance relationship. In doing so, we offer an alternative explanation to the deployment of market orientation as a means to create value, and an explanation that transcends its current linear portrayal. Second, in examining the linear portrayal of market orientation in the public leisure sector, we suggest that the deployment of market orientation may carry contextual implications.

The findings also suggest that current explications of market orientation might inadequately account for the complexity of its deployment. Our findings show that the intelligence generation efforts of the organisation can in part affect the performance returns to an organisation from its responsiveness to market intelligence. But the moderating relationship was only significant on customer performance not business performance, which suggests that intelligence generation is important in shaping responses that secure customer satisfaction and customer value benefits, even if its effect 
on profitability and market share is inconclusive. Accordingly, these findings expand on our understanding of the role intelligence generation can play in the market orientationperformance relationship.

The findings further demonstrate the destructive impact that organisation-wide dissemination of intelligence can have on the response-performance relationship in the public leisure sector, demonstrating a negative significant impact on both forms of performance. These findings support concerns drawn from the bounded rationality and information processing literature (Glazer et al., 1992; Ocasio, 1997) and their recent use in the marketing literature (Souchon et al., 2004; Vyas \& Souchon, 2003). Organisationwide dissemination of information in the public leisure sector appears to create information processing difficulties that can compromise decision-makers’ response to market change (Vyas \& Souchon, 2003). Thompson and McHugh (1991) acknowledge that public sector service organisations have more complex operating environments than traditional commercial organisations, with managerial autonomy also restricted by centrally dictated targets (Butterfield, Edwards, \& Woodall, 2005). Moreover, the range of relevant external constituencies is especially complex in public sector organisations, such as leisure services (Crockford, 1994). This is highlighted by the dual market pressures of meeting customer expectations and securing economic survival. Therefore, excess information generation coupled with processing constraints may be resulting in public leisure managers limiting their responses to the issues they have the most experience with and not necessarily those most significant to service delivery (e.g., Souchon et al., 2004; Vyas \& Souchon, 2003). Specifically, leisure managers’ decisionmaking may draw on their historical knowledge base of community needs (Fenwick \& 
McMillan, 2005). We suggest that leisure managers rely on this in decision-making above wanton information generation and dissemination, which would only serve to slowdown the decision-making process further.

Market orientation may therefore decelerate response in the public leisure sector because as a learning process focused on all aspects of a facility's environment, the intelligence generation effort may overload a leisure manager’s capacity to process this information and use it meaningfully and productively (Grewal \& Tansuhaj, 2001), beyond their prior unique knowledge of the community and service provision.

Subsequently, decision-makers cannot use the full range of information available to them. As such, when information is generated continuously and this intelligence is shared organisation-wide (as opposed to targeted dissemination), the vast quantity of information appears to limit decision-makers ability to process information and take appropriate action in a timely manner because their attention is pulled across multiple fronts (e.g., Ocasio, 1997); thus compromising the response-performance relationship. The relationship found between the deployment of market orientation and performance in the public leisure sector may follow an inverted U shape, such that high levels of market orientation — specifically generation and organisation-wide dissemination of intelligence-reduce performance (Cadogan et al., 2009). We argue that this could be attributed to the bounded rationality and information processing capacity of leisure managers, which subsequently constrains the linear deployment of market orientation. Given that public leisure managers have the sole responsibility to formalise and respond accordingly to market intelligence (Benson \& Henderson, 2005), it is suggested that excess information generation and organisation-wide dissemination will constrain their 
decision-making ability in turn reducing performance returns. The responses of leisure managers are unlikely to be optimal because these decision-makers are forced to filter the abundance of information that confronts them (Ocasio, 1997). This scenario is driven by the organisation-wide dissemination component of market orientation. Less dissemination would allow for better filtering and targeting of market intelligence to those most capable of capitalising on it and such situations would likely benefit performance. The findings therefore suggest a failure of the linear characterisation of the market orientationperformance relationship to account for the complexity of its deployment in the public leisure sector context.

In conclusion, the study contributes to theory with an alternative model of the deployment of market orientation, and this model can form the basis to understand discrepancies in the market orientation-performance relationship. These findings encourage researchers to assess more critically the manner in which market orientation and marketing efforts can add value to organisations. Moreover, we believe that further insights from the public sector can raise questions about assumptions in marketing theory. We add our voice to the growing calls by scholars to provide robust evidence to support marketing's credibility to both private and public organisations' value creation efforts (e.g., Luo \& Donthu, 2006). This study was not without its limitations. First, this study was based on a cross-sectional design, and does not allow absolute causality to be asserted from the data. Second, this study sampled public leisure providers in England. As government structures, service delivery, and resource allocation systems differ between sectors and countries, caution must be exercised against generalising the results to populations markedly different to that examined here. Third, judgements about 
performance, although qualified, have been reported by a single informant and may not sufficiently capture the multi-faceted aspect of this construct, especially for public service providers (Caruana et al., 1999). Fourth, perceptual measures of organisational performance (e.g., business and customer performance) are relied upon as access to objective organisational performance data was largely unavailable and thus could not be employed. We acknowledge this as a limitation. Notwithstanding this, public service provision as a context for the application of market orientation, is worthy of closer scrutiny. In addition, given the findings of this study, research is needed to determine whether this model explains inconsistent results seen in studies of private sector firms.

\section{References}

Atuahene-Gima, K., \& Ko, A. (2001). An empirical investigation of the effect of market orientation and entrepreneurial orientation alignment on product innovation. Organization Science, Vol. 12, 54-74.

Atuahene-Gima, K., \& Murray, J.Y. (2004). Antecedents and outcomes of marketing strategy comprehensiveness. Journal of Marketing, Vol. 68 October, 33-46.

Atuahene-Gima, K., Slater, S.F., \& Olson, E.M. (2005). The contingent value of responsive and proactive market orientations for new product program performance. Journal of Product Innovation Management, Vol. 22, 464-482.

Barclay, D.W., Thompson, R.L., \& Higgins, C.A. (1995). The partial least squares (pls) approach to causal modeling: personal computer adoption and use as an illustration. Technology Studies, Vol. 2 No. 2, 285-309. 
Bagozzi, R.P., \& Yi, Y. (1988). On the evaluation of structural equation models. Journal of the Academy of Marketing Science, Vol. 16 No. 1, 74-94.

Bardin, M., \& Majer, K. (1983). Managing information overload. The Public Relations Journal, Vol. 39 No. 9, 26-28.

Benson, A.M., \& Henderson, S. (2005). Strategic characteristics of sport and recreation provision: an application of SPACE analysis. Managing Leisure, Vol. 10 No. 4, 251-267.

Berg, E.B., Barry, J.J., \& Chandler, J.P. (2008). New public management and social work in Sweden and England. International Journal of Sociology and Social Policy, Vol. 28 No. 3/4, 114-128.

Blackman, D.A., \& Lee-Kelley, L. (2006). The role of human resource development in preventing organisational stagnation. Management Decision, Vol. 44 No. 5, 628643.

Bollen, K.A. (1989). Structural Equations with Latent Variables. New York: Wiley. Browne, M.W., \& Cudeck, R. (1992). Alternative ways of assessing model fit. Sociological Methods and Research, Vol. 21 No. 2, 230-258.

Butler, P., \& Collins, N. (1995). Marketing public sector services: concepts and characteristics. Journal of Marketing Management, Vol. 11 No. 1/3, 83-96.

Butterfield, R., Edwards, C., \& Woodall, J. (2005). The new public management and managerial roles: the case of the police sergeant. British Journal of Management, Vol. 16 No. 4, 329-341.

Cadogan, J., Kuivalainen, O., \& Sundqvist, S. (2009). Export market-oriented behaviour and export performance: quadratic and moderating effects under differing degrees 
of market dynamism and internationalisation. Journal of International Marketing, Vol. 17 No. 4, 71-89.

Cadogan, J.W., Souchon, A.L., \& Procter, D.B. (2008). The quality of market-oriented behaviors: formative index construction. Journal of Business Research, Vol. 61 No. 12, 1263-1277.

Caemmerer, B., \& Banerjee, M. (2009). An exploration of assimilating service relation strategies in the private and the public sector. Journal of Relationship Marketing, Vol. 8, 68-79.

Carmines, E.G., \& McIver, J.P. (1981). Analyzing models with unobserved variables: analysis of covariance structures. In Bohmstedt, G.W. \& Borgatta, E.F. (Eds.), Social Measurement (65-115). Thousand Oaks, CA: Sage Publications.

Caruana, A., Ramaseshan, B., \& Ewing, M.T. (1999). Market orientation and performance in the public sector. Journal of Global Marketing, Vol. 12 No. 3, 5979.

Cervera, A., Molla, A., \& Sanchez, M. (2001). Antecedents and consequences of market orientation in public organisations. European Journal of Marketing, Vol. 35 No. 11/12, 1259-1288.

Chakravarthy, B.S. (1986). Measuring strategic performance. Strategic Management Journal, Vol. 7 No. 5, 437-458.

Cho, T.S., \& Hambrick, D.C. (2006). Attention as the mediator between top management team characteristics and strategic change: the case of airline deregulation. Organization Science, Vol. 17 No. 4, 453-469. 
Clohesy, W.W. (2003). Fund-raising and the articulation of common goods. Nonprofit and Voluntary Sector Quarterly, Vol. 32 No. 1, 128-140.

Coalter, F. (2000). Public and commercial leisure provision: active citizens and passive consumers?. Leisure Studies, Vol. 19 No. 3, 163-181.

Cockburn, I., Henderson, R., \& Stern, S. (2000). Untangling the origins of competitive advantage. Strategic Management Journal, Vol. 21, 1123-1146.

Crockford, D. (1994). Strategic management in privatised business. Long Range Planning, Vol. 27 No. 2, 111-118.

Cyert, R., \& March, J.G. (1963). A Behavioral Theory of the Firm. Englewood Cliffs, NJ: Prentice-Hall.

Delaney, J.T., \& Huselid, M.A. (1996). The impact of human resource management practices on perceptions of organizational performance. Academy of Management Journal, Vol. 39 No. 4, 949-969.

Deshpande, R., \& Webster Jr., F.E. (1989). Organizational culture and marketing: defining the research agenda. Journal of Marketing, Vol. 53 No. 1, 3-15.

Deshpande, R., Farley, J.U., \& Webster Jr., F.E. (1993). Corporate culture customer orientation and innovativeness in Japanese firms: a quadrad analysis. Journal of Marketing, Vol. 57 No. 1, 23-37.

Diamantopoulos, A., \& Hart, S. (1993). Linking market orientation and company performance: preliminary work on Kohli and Jaworski’s framework. Journal of Strategic Marketing, Vol. 1 No. 2, 93-122.

Dickson, P.R. (1992). Toward a general theory of competitive rationality. Journal of Marketing, Vol. 56 No. 1, 69-83. 
Dillman, D.A. (2007). Mail and Internet Surveys: The Tailored Design Method. New Jersey: John Wiley \& Sons.

Dolnicar, S., \& Lazarevski, K. (2009). Marketing in non-profit organisations: an international perspective. International Marketing Review, Vol. 26 No. 3, 275291.

Fenwick, J., \& McMillan, J. (2005). Organisational learning and public sector management: an alternative view. Public Policy and Administration, Vol. 20 No. 3, 42-55.

Fornell, C., \& Larcker, D.F. (1981). Evaluating structural equation models with unobservable variables and measurement error. Journal of Marketing Research, Vol. 18 (February), 39-50.

Glazer, R., Steckel, J.H., \& Winer, R.S. (1992). Locally rational decision making: the distracting effect of information on managerial performance. Management Science, Vol. 38, 212-226.

Gonzalez-Benito, O., Gonzalez-Benito, J., \& Munoz-Gallego, P.A. (2009). Role of entrepreneurship and market orientation in firms' success. European Journal of Marketing, Vol. 43 No. 3/4, 500-522.

Grewal, R., \& Tansuhaj, P. (2001). Building organizational capabilities for managing economic crisis: the role of market orientation and strategic flexibility. Journal of Marketing, Vol. 65 No. 2, 67-80.

Han, J., Kim, N., \& Srivastava, R. (1998). Market orientation and organizational performance: is innovation a missing link. Journal of Marketing, Vol. 62 No. 4, $30-45$. 
Heracleous, L., \& Johnston, R. (2009). Can business learn from the public sector? European Business Review, Vol. 21 No. 4, 373-379.

Ho, Y., \& Huang, C. (2007). Market orientation, strategies and business performance: evidence from Taiwan life insurance industry. Journal of American Academy of Business, Vol. 11 No. 1, 297-303.

Homburg, C., Grozdanovic, M., \& Klarmann, M. (2007). Responsiveness to customers and competitors: the role of affective and cognitive organizational systems. Journal of Marketing, Vol. 71 July, 18-38.

Homburg, C., Krohmer, H., \& Workman, J.P. (2004). A strategy implementation perspective of market orientation. Journal of Business Research, Vol. 57 No. 12, 1331-1340.

Hu, L., \& Bentler, P.M. (1999). Cutoff criteria for fit indices in covariance structure analysis: conventional criteria versus new alternatives. Structural Equation Modeling, Vol. 6 No. 1, 1-55.

Hughes, P., Hughes, M., \& Morgan, R.E. (2010). Why do product-market strategies fail? a sociostructural examination under conditions of adherence. Group \& Organization Management, Vol. 35 No. 5, 606-635.

Hughes, P., Morgan, R.E., \& Kouropalatis, Y. (2008). Market knowledge diffusion and business performance. European Journal of Marketing, Vol. 42 No. 11/12, 13721395.

Hult, G.T.M., \& Ketchen, D.J. (2001). Does market orientation matter: a test of the relationship between positional advantage and performance. Strategic Management Journal, Vol. 22 No. 9, 899-906. 
Jaw, C., Lo, J.Y., \& Lin, Y.H. (2010). The determinants of new service development: service characteristics, market orientation, and actualizing innovation effort. Technovation, Vol. 30 No. 4, 265-277.

Jaworski, B.J., \& Kohli, A.K. (1993). Market orientation: antecedents and consequences. Journal of Marketing, Vol. 57 No. 3, 53-70.

Johanson, J.E. (2009). Strategy formation in public agencies. Public Administration, Vol. 87 No. 4, 872-891.

Kaczynski, A.T. (2008). A more tenable marketing for leisure services and studies. Leisure Sciences, Vol. 30, 253-272.

Kim, N., and Atuahene-Gima, K. (2010). Using exploratory and exploitative market learning for new product development. Journal of Product Innovation Management, Vol. 27, 519-536.

Kline, R.B. (1998). Principles and Practice of Structural Equation Modeling. New York: Guilford Press.

Kohli, A.K., \& Jaworski, B.J. (1990). Market orientation: the construct, research propositions, and managerial implications. Journal of Marketing, Vol. 54 No. 2, 118.

Kohli, A.K., Jaworski, B.J., \& Kumar, A. (1993). MARKOR: a measure of market orientation. Journal of Marketing Research, Vol. 30 No. 4, 467-477.

Kohli, A.K., Shervani, T.A., \& Challagalla, G.N. (1998). Learning and performance orientation of salespeople: the role of supervisors. Journal of Marketing Research, Vol. 35 (May), 263-274. 
Krohmer, H., Homburg, C., \& Workman, J.P. (2002). Should marketing be crossfunctional? Conceptual development and international empirical evidence. Journal of Business Research, Vol. 55 No. 6, 451-465.

Laffin, M., \& Liddle, J. (2006). New perspectives on partnership. International Journal of Public Sector Management, Vol. 19 No. 3, Editorial.

Langerak, F. (2003). An appraisal of research on the predictive power of market orientation. European Management Journal, Vol. 21 No. 4, 447-464.

Lee-Kelley, L., Blackman, D.A., \& Hurst, J.P. (2007). An exploration of the relationship between learning organisations and the retention of knowledge workers. Learning Organization, Vol. 14 No. 3, 204-221.

Lindsay, G., \& Murphy, A. (1996). NSPCC: marketing the ‘solution’ not the problem. Journal of Marketing Management, Vol. 12 No. 8, 707-718.

Luo, X., \& Donthu, N. (2006). Marketing’s credibility: a longitudinal investigation of marketing communication productivity and shareholder value. Journal of Marketing, Vol. 70 October, 70-91.

Macedo, I.M., \& Pinho, J.C. (2006). The relationship between resource dependence and market orientation. European Journal of Marketing, Vol. 40 No. 5/6, 533-553.

Matsuno, K., \& Mentzer, J.T. (2000). The effects of strategy type on the market orientation-performance relationship. Journal of Marketing, Vol. 64 No. 4, 1-16.

Matsuno, K., Mentzer, J.T., \& Özsomer, A. (2002). The effects of entrepreneurial proclivity and market orientation on business performance. Journal of Marketing, Vol. 66 No. 3, 18-32. 
Moorman, C., \& Miner, A.S. (1998). The convergence of planning and execution: improvisation in new product development. Journal of Marketing, Vol. 62 July, 120.

Morgan, N.A., Vorhies, D.W., \& Mason, C.H. (2009). Market orientation, marketing capabilities, and firm performance. Strategic Management Journal, Vol. 30, 909920.

Nelson, L., \& Henderson, S. (2005). Best value and the market orientation of UK recreation centres. Local Government Studies, Vol. 31 No. 2, 237-257.

Narver, J.C., \& Slater, S.F. (1990). The effect of a market orientation on business profitability. Journal of Marketing, Vol. 36 No. 4, 20-35.

Noble, C.H., Sinha, R.K., \& Kumar, A. (2002). Market orientation and alternative strategic orientations: a longitudinal assessment of performance implications. Journal of Marketing, Vol. 66 No. 4, 25-40.

Ocasio, W. (1997). Towards an attention-based view of the firm. Strategic Management Journal, Vol. 18, 187-206.

Ping, R.A. (1995). A parsimonious estimation technique for interaction and quadratic latent variables. Journal of Marketing Research, Vol. 32 August, 336-347.

Podsakoff, P.M., MacKenzie, S.B., Lee, J-Y., \& Podsakoff, N.P. (2003). Common method biases in behavioral research: a critical review of the literature and recommended remedies. Journal of Applied Psychology, Vol. 88 No. 5, 879-903.

Sashittal, H.C., \& Jassawalla, A.R. (2001). Marketing implementation in smaller organisations: definition, framework, and propositional inventory. Journal of the Academy of Marketing Science, Vol. 29, 50-70. 
Shoham, A., Rose, G.M., \& Kropp, F. (2005). Market orientation and performance: a meta-analysis. Marketing Intelligence \& Planning, Vol. 23 No. 5, 435-454.

Shoham, A., Ruvio, A., Vigoda-Gadot, E., \& Schwabsky, N. (2006). Market orientations in the nonprofit and voluntary sector: a meta-analysis of their relationships with organisational performance. Nonprofit and Voluntary Sector Quarterly, Vol. 35 No. 3, 453-476.

Silva, M., Moutinho, L., Coelho, A., \& Marques, A. (2009). Market orientation and performance: modelling a neural network. European Journal of Marketing, Vol. 43 No. 3/4, 421-437.

Siu, N.Y.M., \& Wilson, R.M.S. (1998). Modelling market orientation: an application in the education sector. Journal of Marketing Management, Vol. 14 No. 4/5, 293323.

Slater, S.F., \& Narver, J.C. (1998). Customer-led and market-orientated: let's not confuse the two. Strategic Management Journal, Vol. 19 No. 10, 1001-1006.

Slater, S.F., \& Narver, J.C. (2000). The positive effect of a market orientation on business profitability: a balanced replication. Journal of Business Research, Vol. 48 No. 1, 69-73.

Souchon, A.L., Cadogan, J.W., Procter, D.B., \& Dewsnap, B. (2004). Marketing information use and organisational performance: the mediating role of responsiveness. Journal of Strategic Marketing, Vol. 12, 231-242.

Spector, P.E., \& Brannick, M.T. (1995). The nature and effects of method variance in organizational research. In Cooper, C.L. \& Robertson, I.T. (Eds.), International 
Review of Industrial and Organizational Psychology 10 (249-274). Chichester: Wiley.

Thompson, P., \& McHugh, R. (1991). Work organisations. Macmillan Education Ltd: Hampshire.

Vazquez, R., Alvarez, L.I., \& Santos, M.L. (2002). Market orientation and social services in private non-profit organizations. European Journal of Marketing, Vol. 36 No. 10, 1022-1046.

Vyas, R., \& Souchon, A.L. (2003). Symbolic use of export information: a multidisciplinary approach to conceptual development and key consequences. International Marketing Review, Vol. 20 No. 1, 67-94.

White, D.W., \& Simas, C.F. (2008). An empirical investigation of the link between market orientation and church performance. International Journal of Nonprofit and Voluntary Sector Marketing, Vol. 13, 153-165.

Wilson, D.T. (1996). A longitudinal study of the impact of market structure, firm structure, and market orientation culture on dimensions of small-firm performance. Journal of the Academy of Marketing Science, Vol. 24 No. 1, 27-43.

Zhou, Z., Yim, C.K., \& Tse, D.K. (2005). The effects of strategic orientations on technology- and market-based breakthrough innovations. Journal of Marketing, Vol. 69 No. 2, 42-60. 